\title{
Genetic evidence of population structuring in the neotropical freshwater fish Brycon hilarii (Valenciennes, 1850)
}

\author{
Sanches, A.* and Galetti Jr, PM. \\ Departamento de Genética e Evolução, Universidade Federal de São Carlos - UFSCar, \\ Rodovia Washington Luiz, Km 235, CP 676, CEP 13565-905, São Carlos, SP, Brazil \\ *e-mail: lelesanches@gmail.com \\ Received June 8, 2006 - Accepted September 26, 2006 - Distributed December 1, 2007
}

(With 2 figures)

\begin{abstract}
Brycon hilarii is a migratory fish widely distributed throughout the Paraguay River Basin. It is appreciated in sport fishing and for its superior meat quality. It is also the main species for tourist attraction in the Bonito region (State of Mato Grosso do Sul, Brazil). Considering the lack of information on the genetic structure of the fish of this species, the aim of the present study was to detect the genetic variability of Brycon hilarii through RAPD markers. A total of eighty specimens collected in different seasons at four sites of the Miranda River sub-basin (Paraguay River Basin, Brazil) were used for analysis. The results of genetic similarity, Shannon diversity, and AMOVA revealed differences between the sampling sites. Through AMOVA, differences between populations were more evident among the animals collected during the non-reproductive season, corresponding to a time of less movement of these fish. A population structuring model in which $B$. hilarii appears organized into genetically differentiated reproductive units that coexist and co-migrate through the studied system was suggested, contrasting the currently accepted idea that freshwater migratory fish form large panmictic populations in a determined hydrographic system. Despite the lack of a complete picture regarding the distribution of $B$. hilarii in the studied region, this initial idea on its population genetic structure could be an important contribution to providing aid for management and conservation programs of these fish.
\end{abstract}

Keywords: Bryconinae, Characidae, conservation genetics, population genetics.

\section{Evidência genética de estruturação populacional do peixe neotropical de água doce Brycon hilarii}

\begin{abstract}
Resumo
Brycon hilarii é uma espécie de peixe migrador, distribuída por toda a Bacia do Paraguai, bastante apreciada tanto pela qualidade da carne quanto para a pesca esportiva, além de ser a principal espécie de interesse turístico da região de Bonito (MS, Brasil). Considerando a ausência de informações sobre a estrutura genética dos peixes desta espécie, o presente trabalho visou detectar a variabilidade genética de Brycon hilarii através de marcadores RAPD. Foi estudado um total de 80 exemplares amostrados em diferentes períodos do ano, em 4 localidades da sub-bacia do Rio Miranda (Bacia do Rio Paraguai, Brasil). Os resultados de similaridade genética, de diversidade de Shanon e AMOVA evidenciaram diferenças entre as localidades amostradas. Através da AMOVA, a diferenciação populacional foi mais evidente entre os peixes coletados no período não-reprodutivo, que representa a época de menor deslocamento desses peixes. Desta forma, ao contrário da idéia até então aceita de que os peixes migradores de água doce formam grandes populações panmíticas em um dado sistema hidrográfico, sugere-se a ocorrência de um modelo de sub-estruturação populacional onde os indivíduos de $B$. hilarii se organizam em unidades reprodutivas geneticamente diferenciadas e mantêm sua integridade co-existindo e co-migrando através do sistema estudado. Apesar da falta de um cenário completo a respeito da distribuição de $B$. hilarii na região estudada, esta idéia inicial acerca de sua estrutura genéticopopulacional pode ser uma contribuição muito importante principalmente por fornecer subsídios para planos de manejo e conservação desses peixes.
\end{abstract}

Palavras-chave: Bryconinae, Characidae, genética da conservação, genética de populações. 


\section{Introduction}

Brycon Müller and Troschel 1844 (Bryconinae, Characidae) is considered one of the most species-rich genera in its family, comprising around 40 valid species (Howes, 1982; Lima, 2003), and occurring in the largest hydrographic basins of the neotropical region. It is a fish group of great commercial importance in extractive and sport fishing, as well as in aquaculture (Lima, 2003). The species are rheophilic, inhabiting clear and oxygen-rich river waters, and omnivorous, mainly feeding on fruits, seeds, and insects (Sabino and Sazima, 1999; Lima and Castro, 2000). Some large-sized species undergo long reproductive migrations, generally in the flood season (Howes, 1982; Lima, 2003).

A drastic reduction of these fish has been observed in some Brazilian hydrographic basins in the past twenty years. Six species were recently included on the national list of endangered aquatic species (MMA, 2004). Anthropogenic actions, such as deforestation of ciliary forests, construction of dams and hydroelectrics, drainage for agriculture, water pollution, and overexploitation of natural fish stocks, have been pointed out as causes of the endangerment inflicted upon these fish (Lima and Castro, 2000).

Brycon hilarii (Valenciennes, 1850) is distributed throughout the Paraguay River Basin. This fish constitutes the main tourist attraction of the underwater observation activity developed in the clear waters of rivers in the Bonito region (Central Western Brazil). Bonito is located in the Bodoquena Uplands of the State of Mato Grosso do Sul (MS) and stands out as a national example of proper ecotourism practices (Sabino and Andrade, 2003). Despite its considerable biodiversity, there is an indication that the impact of visitors on the ichthyofauna has increased, leading to a reduction in species richness (Sabino and Andrade, 2003). Nothing is yet known regarding the genetic resources of these natural fish populations.

Currently, molecular markers are applied to assess the genetic variability of natural fish populations in order to identify gene pools and/or fish stocks. The importance of this approach lies on its potential for delimiting priority areas for species conservation and the sustainable use of these resources.

RAPD markers (Williams et al., 1990; Welsh and McClelland, 1990) have been widely employed in fish studies involving the identification of species and hybrids (Barman et al., 2003), as well as the construction of linkage maps (Khoo et al., 2003), inquiries related to aquaculture (Wasko et al., 2004), and the detection of the genetic structure of natural populations (Wasko and Galetti, 2002; Hatanaka and Galetti, 2003; Hassanien et al., 2004). The success of this methodology is due to the fact that it is capable of revealing a high degree of polymorphism and is very useful when there is no information on the genome of the investigated species.

In order to assess the genetic variability of B. hilarii, RAPD markers were used in samples collected during the spawning and non-reproductive seasons at four sites of the Miranda River sub-basin (Paraguay River Basin, MS, Brazil).

\section{Material and Methods}

Samplings were performed at four sites in the Miranda River sub-basin (Paraguay River Basin) in 1999-2000 during both the spawning (floods - November to March) and non-reproductive (dry - April to October) seasons. Site 1, at the Formoso River - Estância dos Rios Farm (21 4' 37.2" $\mathrm{S}$ and 56 21' 43.9' $\mathrm{W})$, and Site 2, at the Peixe River - Santa Julia Farm (20 $51^{\circ}$ ' $45^{\prime \prime} \mathrm{S}$ and $\left.56^{\circ} 30^{\prime} 51^{\prime \prime} \mathrm{W}\right)$, are both tributaries of the Miranda River. At these sites, the fish are not artificially fed, because they are on private properties with no tourist activities. Site 2 is also characterized by the presence of waterfalls. Site $3\left(20^{\circ} 43\right.$ ' 26.1" $\mathrm{S}$ and $\left.56^{\circ} 8,3.5^{\prime \prime} \mathrm{W}\right)$ is located in the main channel of the Miranda River, and is characterized by intensive fishing and daily fish fattening. Site 4 is at the Formoso River (Padre Island, $21^{\circ} 7^{\prime} \mathrm{S}$ and $56^{\circ} 10^{\prime} \mathrm{W}$ ), where the fish are frequently fed (Figure 1 ).

A total of 80 individuals were sampled. Blood samples were collected from the caudal peduncle with the use of hypodermic syringes containing 0.5 M EDTA. Before being released to the capture sites, the animals were marked by nylon strings tied to the dorsal fin base in order to prevent recapture.

The genomic DNA was extracted from the blood (Lahiri and Nurnberger, 1991). A total of thirteen $10 \mathrm{bp}$ oligonucleotides (Gibco BRL) were initially tested as single primers in eight individuals, two from each collection site. Experiments were performed with the aim of

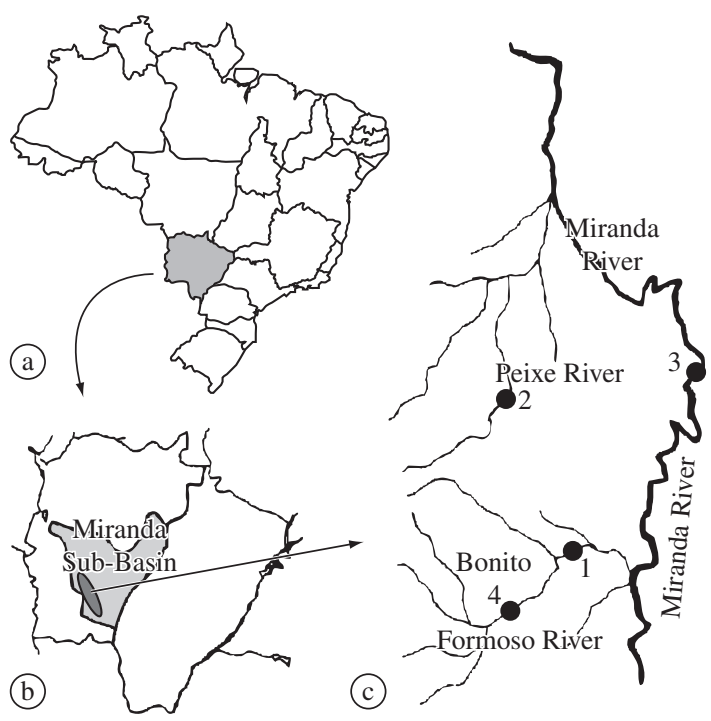

Figure 1. Collection sites: a) Map of Brazil, highlighting the State of Mato Grosso do Sul (MS); b) MS State - Miranda Sub-basin; and c) 1-Formoso River/Estância dos Rios Farm, 2-Peixe River/Santa Júlia Farm, 3-Miranda River, 4-Formoso River/Padre Island. 
testing the effect of different concentrations of the components and hybridization temperatures of the PCR in order to standardize the conditions that produce the best results and band repeatability. To certify the repeatability of the amplification products, all reactions were repeated at least twice in such a way that only strong and well-defined bands appearing in two independent reactions were considered for the analysis. Of the primers tested, three with high repeatability were chosen for the analysis. The final amplification reaction consisted of $50 \mathrm{ng}$ of DNA, 5 pmol of a single primer, $1 \times$ PCR buffer $(50 \mathrm{mM} \mathrm{KCl}$, $10 \mathrm{mM}$ Tris $\mathrm{pH} 8.3$ ), $3 \mathrm{mM} \mathrm{MgCl}, 125 \mu \mathrm{M}$ of each $\mathrm{dNTP}$, and $1 \mathrm{U}$ of Taq polymerase in a final volume of $25 \mu \mathrm{l}$. A negative control was included in each set of reactions (Figure 2). The amplification program consisted of 40 cycles with a $94{ }^{\circ} \mathrm{C}$ denaturing temperature for 1 minute, an annealing temperature of $37^{\circ} \mathrm{C}$ for $1.5 \mathrm{~min}$ utes, and an extension temperature of $72{ }^{\circ} \mathrm{C}$ for $3 \mathrm{~min}$ utes, in an MJ Research thermocycler PT 100 model. Amplification products were submitted to electrophoresis in a $1.4 \%$ agarose gel for approximately 3 hours at an average voltage of $85 \mathrm{~V}$. The gels, stained with ethidium bromide (Sambrook et al., 1989), were visualized under UV light, digitalized, and analyzed through the Kodak EDAS (Electrophoresis Documentation and Analysis System) 290. Molecular weight was estimated with a molecular weight marker (Figure 2).

Binary matrixes of the band patterns of each individual were constructed, where the absence or presence of a band was considered as 0 or 1 , respectively (Figure 2). The dominant inheritance of RAPD markers is well known, and using classical data analysis based on the gene and genotypic frequency estimates that assume the Hardy-Weinberg Equilibrium (HWE) is controversial (Excoffier et al., 1992; Lynch and Milligan, 1994). Therefore, two approaches were considered for statistical analysis. The first was based on the supposition that the analyzed populations are in Hardy-Weinberg equilibrium and that the alleles from different loci do not co-

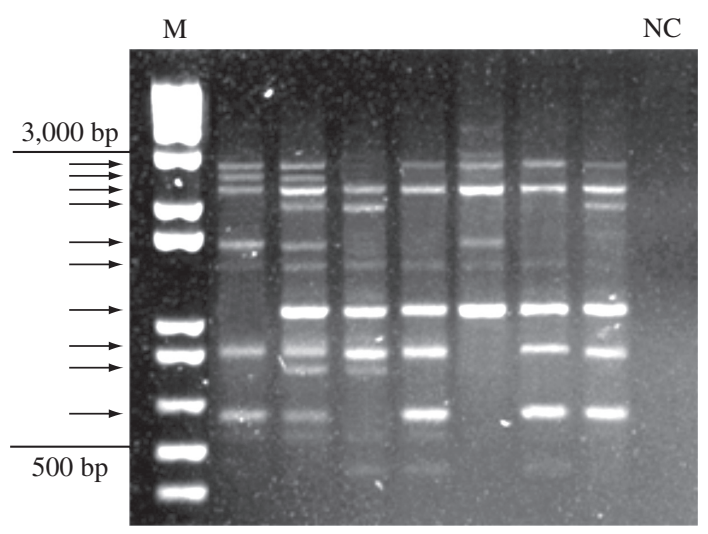

Figure 2. RAPD patterns of seven individuals of Brycon hilarii using OPP-13 primer. The arrows denote polymorphic fragments; $1 \mathrm{~Kb}$ plus Molecular Weight Marker (M), and negative control (NC). migrate to a same gel position, where a visible fragment represents the dominant homozygous genotype and its absence represents the recessive homozygote (Lynch and Milligan, 1994; Wasko and Galetti, 2002; Hatanaka and Galetti, 2003). Jaccard (1901) similarity indexes were determined and similarity matrixes were constructed using the NTSYS software, version 1.8 (Rohlf, 1993). Differences in the similarity coefficients obtained for each site were tested (Zar, 1984) using the BioEstat 2.0 program (Ayres et al., 2000).

In the second approach, data were analyzed independent of the Hardy-Weinberg equilibrium supposition, and the individual band patterns were treated as phenotypic characters (Excoffier et al., 1992). Through the binary matrixes of band presence/absence, a Euclidian distance matrix was obtained between the pairs of individuals. The Euclidian distance is equivalent to a simple squared count of the number of differences between the two individual RAPD patterns:

$$
\delta^{2}{ }_{x y}=\sum_{i=1}^{\mathrm{S}}\left(x_{i}-y_{i}\right)^{2}
$$

where $x$ and $y$ are the individual RAPD patterns and $s$ is the number of valid fragments (Excoffier et al., 1992). This distance matrix was then submitted to AMOVA (analysis of molecular variance), which consists of a classical variance analysis of the distances, subdividing the variation into hierarquical levels (Excoffier et al., 1992 ), in this case, within and among the four populations. Thus, AMOVA provided $\Phi_{S T}$ values analogous to Wright's (1978) $F_{S T}$, and through a non-parametric procedure of random permutations $(10,000)$, the initial hypothesis of no genetic structuring between populations was tested.

The Shannon diversity index $\left(H_{0}\right)$,

$H_{0}=-\Sigma p_{i} \log _{2} p_{i}$

where $p_{i}$ is the frequency of a given RAPD fragment, was used to estimate the degree of intrapopulation diversity (Lewontin, 1972). To determine diversity distribution, average intrapopulation diversities

$H_{\text {pop }}=1 / n-\Sigma H_{0}$

where $n$ is the number of populations, and species total diversity considering all individuals conjunctly

$H_{s p}=-\Sigma p_{i} \log _{2} p_{i}$

where $p_{i}$ is the frequency of a band in all analyzed individuals were calculated. Multiple statistical analyses followed the Bonferroni correction (Rice, 1989).

\section{Results}

Based on the repeatability and intensity of the amplicons produced in subsequent reactions by the three selected primers, a total of 32 fragments with estimated sizes between 500 and 3,000 bp were considered for the analyses (Figure 2). No diagnostic band - a band exclu- 
sive to a single population - was found, indicating that the observed genetic divergence is a result of the different fragment frequencies between populations.

Table 1 displays the mean Jaccard similarity coefficient values that were calculated for each site. Values were significantly different (Kruskal-Wallis KW $=105.92$, $\mathrm{p}<0.0001$ ) between all sites (Mann-Whitney Test, $P<0.005$ for all pair comparisons) with the highest values belonging to Sites 1 and 2 .

The highest genetic diversity estimative (Table 2) was found in Population 4 (0.5832), and the lowest was

Table 1. Mean similarity coefficient (Mean \pm Standard Deviation) of Brycon hilarii collected at four sites

\begin{tabular}{lc}
\hline \multicolumn{1}{c}{ Sites } & $\begin{array}{c}\text { Mean similarity } \\
\text { coefficient }\end{array}$ \\
\hline Formoso River/ & $0.75 \pm 0.14$ \\
Estância dos Rios Farm (1) & \\
Peixe River (2) & $0.71 \pm 0.20$ \\
Miranda River (3) & $0.66 \pm 0.19$ \\
Formoso River / Padre Island (4) & $0.63 \pm 0.21$ \\
\hline
\end{tabular}

Table 2. Genetic diversity estimates: $H_{0}=$ diversity within each population of Brycon hilarii; $H_{s p}=$ diversity within species; $H_{p o p}=$ average diversity within populations.

\begin{tabular}{cc}
\hline Population & $\boldsymbol{H}_{0}$ (standard deviation) \\
\hline 1 & $0.4726(0.2506)$ \\
2 & $0.4904(0.2599)$ \\
3 & $0.5482(0.2239)$ \\
4 & $0.5832(0.1722)$ \\
$H_{s p}$ & $0.5640(0.1681)$ \\
$H_{p o p}$ & 0.525 \\
\hline
\end{tabular}

in Population 1 (0.4726). The diversity estimative for the species considering the total number of individuals $\left(H_{s p}=0.5640\right)$ was similar to the mean intrapopulation diversity $\left(H_{p o p}=0.525\right)$. The proportions of diversity within $\left(H_{p o p} / H_{s p}\right)$ and between $\left(\left(H_{s p}-H_{p o p}\right) / H_{s p}\right)$ populations indicated that $93 \%$ of the total diversity is attributed to intrapopulation diversity and only $7 \%$ is attributed to interpopulation diversity.

AMOVA (Table 3 ) revealed a significant genetic differentiation between populations $\left(\Phi_{S T}=0.034 ; \mathrm{P}<0.0032\right)$, although the pairwise comparisons did not reveal a genetic differentiation between all population pairs analyzed (Table 4). Of the total variation, 3.44\% was attributed to interpopulation divergence and $96.56 \%$ to the individual differences within populations. A higher genetic differentiation between populations $\left(\Phi_{S T}=0.108 ; P=0.0002\right)$ was detected in the non-reproductive season (Table 3 ) and, in contrast to the spawning season, there was a considerable rise in the participation of interpopulation divergences in the total variation $(10.81 \%)$ and a consequent reduction in intrapopulation variation $(89.19 \%)$.

\section{Discussion}

The RAPD analysis was adequate for the evaluation of genetic variation within and between populations of the freshwater fish $B$. hilarii. The major concerns reported for RAPD analysis (Benter et al., 1995) were minimized with a negative control in all sets of reactions as well as their standardization and repetitions. These safety measures were considered in order to overcome the repeatability problem and make the method more reliable.

In the present study, a significant population structuring was detected in the migratory fish $B$. hilarii, although most of the genetic diversity occurred within populations rather than between them.

Table 3. Analysis of molecular variance (AMOVA) among 4 populations of Brycon hilarii considering the total number of individuals from each population, individuals collected only in the non-reproductive season, and those from the spawning season. The data show the degrees of freedom $(d f)$, sum of squared deviation $(S S D)$, mean squared deviation $(M S D)$, variance component estimates, the percentage of total variance that each component contributed, and the probability of obtaining by chance alone a more extreme variance component than the observed values ( $P$-value). The $P$-values were calculated from a random permutation test (10,000 replicates).

\begin{tabular}{|c|c|c|c|c|c|c|c|}
\hline Season sample & $\begin{array}{l}\text { Source of } \\
\text { variation }\end{array}$ & $d f$ & $S S D$ & $M S D$ & $\begin{array}{c}\text { Variance } \\
\text { component }\end{array}$ & $\begin{array}{c}\text { Total } \\
\text { variance }(\%)\end{array}$ & $P$-value \\
\hline \multirow[t]{2}{*}{ Total } & $\begin{array}{l}\text { Between } \\
\text { populations }\end{array}$ & 3 & 23.100 & 7.700 & 0.1602 & 3.44 & 0.0032 \\
\hline & $\begin{array}{l}\text { Within } \\
\text { populations }\end{array}$ & 76 & 341.700 & 4.496 & 4.4961 & 96.56 & - \\
\hline \multirow[t]{2}{*}{$\begin{array}{l}\text { Non- } \\
\text { Reproductive }\end{array}$} & $\begin{array}{l}\text { Between } \\
\text { populations }\end{array}$ & 3 & 26.087 & 8.696 & 0.5100 & 10.81 & 0.0002 \\
\hline & $\begin{array}{l}\text { Within } \\
\text { populations }\end{array}$ & 32 & 134.691 & 4.209 & 4.2091 & 89.19 & - \\
\hline \multirow[t]{2}{*}{ Spawning } & $\begin{array}{l}\text { Between } \\
\text { populations }\end{array}$ & 3 & 20.064 & 6.688 & 0.2024 & 4.31 & 0.0316 \\
\hline & $\begin{array}{l}\text { Within } \\
\text { populations }\end{array}$ & 40 & 179.822 & 4.496 & 4.4956 & 95.69 & - \\
\hline
\end{tabular}


Table 4. AMOVA of pairwise Brycon hilarii populations considering the total of individuals, individuals collected only in the non-reproductive season, and those from the spawning season. Above diagonal - P-values calculated from a random permutation test $\left(10,000\right.$ replicates). Below diagonal $-\Phi_{S T}$ values between populations. *Significant $P$-value following Bonferroni correction $(P<0.008)$.

\begin{tabular}{|c|c|c|c|c|c|c|c|c|c|c|c|c|}
\hline & \multicolumn{4}{|c|}{ Total } & \multicolumn{4}{|c|}{ Non-Reproductive } & \multicolumn{4}{|c|}{ Spawning } \\
\hline & 1 & 2 & 3 & 4 & 1 & 2 & 3 & 4 & 1 & 2 & 3 & 4 \\
\hline 1 & - & 0.083 & $0.007 *$ & 0.028 & - & 0.044 & $0.007 *$ & $0.003 *$ & - & 0.056 & 0.043 & 0.541 \\
\hline 2 & 0.023 & - & 0.010 & 0.176 & 0.065 & - & 0.016 & $0.007 *$ & 0.049 & - & 0.015 & 0.313 \\
\hline 3 & 0.047 & 0.052 & - & 0.092 & 0.141 & 0.140 & - & 0.556 & 0.058 & 0.087 & - & 0.108 \\
\hline 4 & 0.044 & 0.015 & 0.026 & - & 0.147 & 0.136 & -0.019 & - & -0.015 & 0.027 & 0.033 & - \\
\hline
\end{tabular}

There are many reports of population structuring or differentiation within a single hydrographic system related to environmental, biological, or anthropogenic factors (Nesbo et al., 1998; Hatanaka and Galetti, 2003; Hassanien et al., 2004). In the Nile tilapia, the pronounced differentiation found between the Nile River populations and lake populations may reflect the particular selective pressures of these two different types of environment (Hassanien et al., 2004). A good example of the influence of biological factors on the structure of populations is the identification of genetic differentiations between the anadromous and stationary perch (Perca fluviatilis) of the Baltic Sea (Nesbo et al., 1998). Reproductive behavior constitutes a decisive factor in the population subdivision of the species. One anthropogenic factor that has inflicted severe damage upon natural freshwater populations is the construction of artificial dams, which can split a previously continuous population into separated upstream and downstream gene pools (Yamamoto et al., 2004).

Thus far, little is known on the genetic structure of Brazilian freshwater fish populations (Sivasundar et al., 2001; Almeida et al., 2003). In Prochilodus argenteus (cited as P. marggravii), RAPD analysis was able to reveal genetic differentiation among three sites in the São Francisco River, Brazil (Hatanaka and Galetti, 2003). A similar situation was also reported for Brycon orthotaenia (cited as B. lundii) studied in this same hydrographic basin (Wasko and Galetti, 2002). In the latter study, the authors detected the presence of a diagnostic band in $100 \%$ of the individuals of one site and only in $27 \%$ of the individuals of an adjacent site. Also in other species of this genus, Brycon opalinus, which is endemic of the Paraíba do Sul Basin (Brazil), a genetic differentiation between populations along the basin was revealed through mtDNA and microsatellite markers (Hilsdorf et al., 2002; Barroso et al., 2003).

The differences between populations observed in B. hilarii were more evident in the non-reproductive season, corresponding to a time of less movement of these fish. The factors that led to this genetic differentiation are still unknown, as these fish present an enormous vagility and undergo long migrations. It is important to point out that since significant differences were detected between population subunits, it should be assumed that these fish organize themselves during the spawning period in such a way in order to maintain the integrity of each subunit residing in the system. Thus, in contrast to the currently accepted idea of large panmictic populations of neotropical, migratory freshwater fish, these findings indicate the existence of population structuring where these reproductive units somehow co-migrate and co-exist in an organized fashion in the various hydrographic systems (Wasko and Galetti, 2002; Hatanaka and Galetti, 2003).

Assuming the existence of population structuring in B. hilarii of the studied freshwater system, the largest genetic diversity detected between individuals from Padre Island (4) and the Miranda River (3) may reflect a juxtaposition of population strata or varied reproductive units, as there is an increased availability of artificial food in these places, which may promote an accumulation of individuals through the reduction in competition for food. Moreover, the Miranda River, with a length of 697 km, constitutes the main channel of the Miranda sub-basin, which has $43,787 \mathrm{~km}^{2}$ of drainage area, receiving waters from rivers that run through the municipal district of Bonito, as well as twelve others (SEMA, 1995). It is considered one of the main rivers of the Pantanal Region, where numerous marginal and nutrient-rich lagoons, that are ideal for feeding, are formed by the overflow of its waters during flood seasons. A different situation was observed at Sites 1 and 2, where genetic similarity was higher. At these sites, fish are not artificially fed and, therefore, do not have the same availability of food resources as in the other sites. Furthermore, as the spawning season corresponds to the time of reproductive co-migration of these population subunits, no interpopulation differentiation was observed in comparison to the non-reproductive season.

Despite the lack of a complete picture regarding the distribution of $B$. hilarii in the analyzed region, RAPD analysis contributed toward an initial idea on its population genetic structure and could provide an important contribution to the management and conservation of this fish.

Acknowledgments - The authors are grateful to Fundação O Boticário de Proteção à Natureza (FBPN), Coordenação de Aperfeiçoamento de Pessoal de Nível Superior (CAPES), and Conselho Nacional de Desenvolvimento Científico e Tecnológico (CNPq) for financial support. 


\section{References}

ALMEIDA, FS., SODRÉ, LMK. and CONTEL, EPB., 2003. Population structure analysis of Pimelodus maculatus (Pisces, Siluriformes) from the Tietê and Paranapanema Rivers (Brazil). Genet. Mol. Biol., vol. 26, no. 3, p. 301-305.

AYRES, M., AYRES JR., M., AYRES, DL. and SANTOS, AS., 2000. BioEstat 2.0: aplicações estatísticas nas áreas das ciências biológicas e médicas. Brasília, Sociedade Civil Mamirauá (Belém), CNPq.

BARMAN, HK., BARAT, A., YADAV, BM., BANERJEE, S., MEHER, PK., REDDY, PVGK. and JANA, RK., 2003. Genetic variation between four species of Indian major carps as revealed by random amplified polymorphic DNA assay. Aquaculture, vol. 217 , no. 1, p. 115-123.

BARROSO, RM., HILSDORF, AWS., MOREIRA, HLM., MELLO, AM., GUIMARÃES, EF., CABELLO, PH. and TRAUB-CSEKO, YM., 2003. Identification and characterization of microsatellites loci in Brycon opalinus (Cuvier, 1819) (Characiforme, Characidae, Bryconinae). Mol. Ecol. Notes, vol. 3, p. 297-298.

BENTER, T., PAPADOPOULOS, S., PAPE, M., MANNS, M. and POLIWODA, H., 1995. Optimization and reproducibility of random amplified polymorphic DNA in human. Anal. Biochem., vol. 230 , no. 1, p. 92-100.

EXCOFFIER, L., SMOUSE, PE. and QUATTRO, JM., 1992. Analysis of molecular variance inferred from metric distances among DNA haplotypes: application to human mitochondrial DNA restriction sites. Genetics, vol. 131, no. 2, p. 479-491.

HASSANIEN, HA., ELNADY, M., OBEIDA, A. and ITRIBY, H., 2004. Genetic diversity of Nile tilapia populations revealed by randomly amplified polymorphic DNA (RAPD). Aquac Res., vol. 35 , no. 6, p. 587-593.

HATANAKA, T. and GALETTI JR, PM., 2003. RAPD markers indicate the occurrence of structured populations in a migratory freshwater fish species. Genet. Mol. Biol., vol. 26, no. 1, p. 19-25.

HILSDORF, AWS., AZEREDO-ESPIN, AML., KRIEGER, MH., KRIEGER, JE., 2002. Mitochondrial DNA diversity in wild and cultured populations of Brycon opalinus (Cuvier, 1819) (Characiformes, Characidae, Bryconinae) from the Paraíba do Sul Basin, Brazil. Aquaculture, vol. 214, no. 1, p. 81-91.

HOWES, G., 1982. Review of the genus Brycon (Teleostei, Characoidei). Bulletin of the British Museum (Natural History) of Zoology, vol. 43, no. 1, p. 1-47.

JACCARD, P., 1901. Étude comparative de la distribution florale dans une portion des Alpes et des Jura. Bulletin de la Société Vaudoise des Sciences Naturelles, vol. 37, p. 547-579.

KHOO, G., LIM, MH., SURESH, H., GAN, DKY., LIM, KF., CHEN, F., CHAN, WK., LIM, TM. and PHANG VPE., 2003. Genetic linkage maps of the guppy (Poecilia reticulata): assignment of RAPD markers to multipoint linkage groups. Mar. Biotech., vol. 5, no. 3, p. 279-293.

LAHIRI, DK. and NURNBERGER JR, JI., 1991. A rapid nonenzymatic method for the preparation of HMW DNA from blood for RFLP studies. Nucleic Acids Res., vol. 19, no. 19, p. 5444.

LEWONTIN, RC., 1972. The apportionment of human diversity. In DOBZHANSKY, TH., HECHT, MK. and STEERE, WC. (eds.). Evolutionary Biology. New York, Appleton-CenturyCrofts, p. 381-398.

LIMA, FCT., 2003. Subfamily Bryconinae (Characins, tetras). In REIS, RE., KULLANDER, SO. and FERRARIS JR, CJ. (eds.). Check List of the Freshwater Fish of South and Central America. Porto Alegre, EDIPUCRS, p. 174-181.

LIMA, FCT. and CASTRO, RMC., 2000. Brycon vermelha, a new species of characid fish from the Rio Mucuri, a coastal river of eastern Brazil (Ostariophysi: Characiformes). Ichthyol. Explor. Fres., vol. 11, no. 2, p.155-162.

LYNCH, M. and MILLIGAN, BG., 1994. Analysis of population genetic structure with RAPD markers. Mol. Ecol., vol. 3, no. 2, p. 91-99.

MMA, 2004. Lista Nacional de Espécies de Invertebrados Aquáticos e Peixes Ameaçadas de Extinção. Ministério do Meio Ambiente. Diário Oficial da União, seção 1, p. 136-142.

NESBO, CL., MAGNHAGEN, C. and JAKOBSEN, KS., 1998. Genetic differentiation among stationary and anadromous perch (Perca fluviatilis) in the Baltic Sea. Hereditas, vol. 129, p. 241-249.

RICE, WR., 1989. Analyzing tables of statistical tests. Evolution, vol. 43 , no. 1 , p. 223-225.

ROHLF, FJ., 1993. NTSYS-PC: Numerical taxonomy and multivariate analysis system, version 1.80. New York, Steauket, Applied Biostatistic.

SABINO, J. and ANDRADE, LP., 2003. Uso e conservação da ictiofauna no ecoturismo da região de Bonito, Mato Grosso do Sul: o mito da sustentabilidade ecológica no rio Baía Bonita (Aquário Natural de Bonito). Biota Neotropica, vol. 3, no. 2, p. 1-9.

SABINO, J. and SAZIMA, I., 1999. Association between fruiteating fish and foraging monkeys in western Brazil. Ichthyol. Explor. Fres., vol. 10, no. 4, p. 309-312.

SAMBROOK, J., FRITSCH, EF. and MANIATIS, T., 1989. Molecular cloning. A laboratory manual. New York, Cold Spring Harbor Laboratory Press.

SEMA, 1995. Proposta de Enquadramento dos Corpos de Água das Sub-Bacias dos Rios Miranda, Taquari e Imbiruçu. Campo Grande, Secretaria de Estado do Meio Ambiente, Centro de Controle Ambiental.

SIVASUNDAR, A., BERMINGHAM, E. and ORTÍ, G., 2001. Population structure and biogeography of migratory freshwater fish (Prochilodus: Characiformes) in major South American Rivers. Mol. Ecol., vol. 10, no. 2, p. 407-417.

WASKO, AP. and GALETTI JR, PM., 2002. RAPD analysis in the Neotropical fish Brycon lundii: genetic diversity and its implications for the conservation of the species. Hydrobiologia, vol. 474, no. 1-3, p. 131-137.

WASKO, AP., MARTINS, C., OLIVEIRA, C., SENHORINI, JA. and FORESTI, F., 2004. Genetic monitoring of the Amazonian fish matrinchã (Brycon cephalus) using RAPD markers: insights into supportive breeding and conservation programmes. J. Appl. Ichthyol., vol. 20, no. 1, p. 48-52.

WELSH, J. and MCCLELLAND, M., 1990. Fingerprinting genomes using PCR with arbitrary primers. Nucleic Acids Res., vol. 18 , no. 24 , p. $7213-7218$. 
WILLIAMS, JGK., KUBELIK, AR., LIVAK, KJ., RAFALSKI, JÁ. and TINGEY, SV., 1990. DNA polymorphisms amplified by arbitrary primers are useful as genetic markers. Nucleic Acids Res., vol. 18, no. 22, p. 6531-6535.

WRIGHT, E., 1978. Evolution and genetics of populations (Vol. 2): The theory of gene frequencies. London, University of Chicago Press.
YAMAMOTO, S., MORITA, K., KOIZUME, I. and MAEKAWA, K., 2004. Genetic differentiation of whitespotted charr (Salvelinus leucomaenis) populations after habitat fragmentation: Spatial-temporal changes in gene frequencies. Conserv. Genet., vol. 5, no. 4, p. 529-538.

ZAR, JH., 1984. Biostatistical Analysis. London, Prentice-Hall International. 
